\title{
12 Catholic development ethics, mining, and peace: attending to the market's limitations
}

\author{
Albino Barrera, OP
}

\section{Introduction: a straightforward link}

The link between mining, development ethics, and peace is straightforward. Processes and outcomes in mining are invariably and inevitably shaped by markets, even when occurring in nationalized or socialist, centralized economies. After all, both the input and output of mining are ultimately allocated via markets. Both upstream and downstream requirements of mining pass through markets.

Mining markets, like all markets, have significant limitations. They do not arise nor operate smoothly on their own, but are dependent on institutional preconditions, such as the rule of law and a mechanism for property ownership and enforcement. Furthermore, left on their own, markets privilege allocative efficiency over all other possible social goals. This singular focus on allocative efficiency accounts for the much-touted strength of markets in effectively allocating scarce resources to their most valued uses. There is, to date, no other social institution or arrangement that comes close to what markets are able to orchestrate-coordinating the economic decisions of billions of economic actors and firms widely dispersed across the entire world on what to produce, in what quantities and quality, for whom, when, where, with what kind of inputs, in what manner, and at what price to sell. Unfortunately, such accomplishment often comes at the expense of neglecting or even working against other worthwhile socioeconomic goals, such as equity, social harmony, and sustainability. Herein lies the role of development ethics and the connection to peace.

Development ethics poses a number of critically important questions. To what end is socioeconomic life pursued? Who should benefit and who should bear costs? To what degree are market participants accountable for the consequences of their economic activity? What are their obligations to their fellow market participants? These are but some of the questions raised in this field. Development ethics clearly has a hand in shaping the public economic ethos that sets the formal and informal rules governing socioeconomic life, including market exchange (see Gasper 2012; Goulet 2006). Such public morality determines what market processes and outcomes are 
acceptable or unacceptable in the community, and what remedial measures are necessary. ${ }^{1}$ These standards change over time and vary across different communities, depending on their respective populations' evolving ethical thinking. Development ethics, in turn, is animated by the philosophical and theological commitments held by the community. It is through development ethics that Catholic social thought and praxis offer their contribution to socioeconomic life, including in the mining sector.

A word of caution: it would be a mistake to juxtapose market economics and development ethics as competing poles with opposed goals. Far from being rivals, market economics and development ethics complement each other. In particular, socioeconomic life would not be sustainable in the long term if it were to operate on the basis of allocative efficiency alone. History and empirical evidence attest to the importance of equity and social harmony in reaching the economic goals of allocative efficiency, growth, and stability. Note that among the most stable and successful communities are those with a sizable middle class (the consequence of equity as a social goal). The six socioeconomic goals-allocative efficiency, growth, stability, equity, social harmony, and sustainability—need each other in order to be complete and enduring in their respective accomplishments. Stated in another way, the economics of market operations call for and require development ethics. Markets need development ethics because while they are adept and incomparable when it comes to effecting allocative efficiency, growth, and stability, they are often deficient when it comes to equity, social harmony, and sustainability. ${ }^{2}$ And peace is a necessary condition for those goals.

The market's limitations manifest in different ways across different types of economic activities, including mining. Mining often aggravates the market's limitations, thereby making it that much more important to be attentive to what development ethics has to offer. This essay examines six of the more significant market limitations prevalent in the mining sector and considers what extra-market remedies are needed (development ethics) and what Catholic social thought and praxis have to offer. It is a contribution to what can be called mining development ethics, that is, the extra-market interventions and oversight that are needed to put mining sector processes and outcomes in the service of peace and the common good.

\section{Issue \#1: Mining's damage to the environment and technical externalities as a market limitation}

A clear example of market limitation is the problem of technical externalities, the most famous example of which is pollution. In the absence of government or community regulations, firms can simply dump their waste in the commons (air, water, and land), leaving the rest of the community to suffer the consequences and bear the cost of cleanup. Such a situation is inequitable, threatens peace, and is unsustainable. Even neoclassical 
economic theory finds it problematic because such technical externalities impede allocative efficiency. The private cost of producing such goods or services is not equal to their social cost. Without constraints, polluting firms can, in effect, free-ride on the rest of the community. Neoclassical economic policy rectifies such deficiencies via taxes, outright regulation, or a combination (see Pigou 1920 [2013]). This is one issue in which development ethics and neoclassical economic theory converge in their conclusion on the need for extra-market intervention to rectify technical externalities.

Among the most common complaints against mining industries is their damage to the environment. Without regulatory oversight, mining companies tend to leave contaminated air and water, toxic dumps, tailings, and badly scarred landscapes in the wake of their operations. ${ }^{3}$ Both neoclassical economic theory and development ethics are in agreement that such conduct is unacceptable and has to be rectified. Reaching a broad societal consensus on the need to hold mining companies accountable for ecological damage should be relatively easy because there are strong economic and ethical reasons behind such clamor. Mining firms and their shareholders should not be able to reap the benefits while leaving the associated costs to unwitting third parties (see Okonta and Douglas, 2001; Martinez-Alier 2001; McBeth 2018). Allowing them to leave such ecological damage unaddressed has clear adverse impacts on the common good, and conflict and instability are exacerbated when there is inequity in the distribution of costs and benefits.

Ecological protection is a position of mining development ethics that enjoys wide agreement. Catholic social thought and praxis offer their principle of stewardship, that is, the moral obligation to care for and use the gifts of God, the earth and its goods, wisely and well. In Laudato Si, Pope Francis (2015) considered stewardship of the earth through the concept of integral ecology, which calls for integrating environmental concerns with other aspects of social and economic justice, such as justice for the poor, who often suffer disproportionately from the environmental harm caused by mining and the way mining's environmental degradation can drive conflict.

\section{Issue \#2: Mining and the amoral nature of markets}

Markets facilitate economic exchange but are not designed to evaluate, much less judge, the rightness or wrongness of such transactions. Markets only require that one party has purchasing power and another has possession of a good or service in order to consummate an exchange. Unfortunately, this sidesteps the fundamental question of how the community ought to allocate the scarce goods of the earth. By effort, allocative efficiency, merit, need, contribution, parity, or another standard? There are as many criteria as there are philosophical commitments and views on what the good life entails. 


\section{Albino Barrera, OP}

Markets are not designed to make such choices for the larger community because they are merely contractual social devices that we use to orchestrate a whole series of difficult decisions on what to produce, for whom, how much, in what manner, and who gets priority. They do not distinguish between genuine needs and whimsical wants because markets consider only purchasing and bargaining power in consummating exchanges. This gives preeminence to consumer sovereignty. Allocative efficiency, in effect, trumps all the other possible and perhaps even more important goals of socio-economic life.

This is an unworkable market dynamic whether viewed from a practical angle or from the viewpoint of ethics. In actual practice, markets can only function within the framework of a minimum number of extra-market interventions and institutions (such as rule of law, private property ownership and enforcement, etc.). Thus, government and civil society have significant roles in the marketplace. In their own turn, government and civil society are shaped by the philosophical and religious commitments of their membership and leadership. This gives rise to the manifold and varied extramarket interventions of different types of political economies (e.g., Western market capitalism, China's state capitalism, Cuba and Venezuela's socialist economies). Development ethics and Catholic social thought have much to contribute in this societal process of reining in market processes and supplementing their underlying singular pursuit of allocative efficiency. For example, consider some of the problematic outcomes in the mining sector in the wake of an exclusive reliance on purchasing and bargaining power in allocating societal resources: unsafe working conditions, one-sided revenue sharing between a multinational corporation (MNC) and a host country, inequitable revenue sharing within the host country, and inadvertent material cooperation in wrongdoing. We examine each of these briefly.

\section{Unsafe and poor working conditions}

Because markets are allocative rather than normative in their function, they do not and cannot deal with coercive contracts or unequal bargaining power and resulting economic compulsion. The mining industry provides the earliest example of this market limitation in the modern economy. Much has been written on working conditions in British mines early in the Industrial Revolution, and we need not rehearse them here. It is sufficient to note that such abuses precipitated the earliest examples of widespread social unrest that ultimately compelled extra-market intervention, when Parliament passed legislation that mandated workplace safeguards (Mills 2010).

Today, we see the same dynamic at work. The poor and the unemployed accept unsafe and physically taxing and unhealthy working conditions in mines because they are desperate for income. Social legislation, potential lawsuits, scrutiny from non-governmental organizations, or the risk of bad 
publicity level the playing field and compensate for workers' inability to negotiate better conditions for themselves. The need for such extra-market interventions arises because markets consummate economic exchanges solely on the basis of purchasing and bargaining power, not the qualitymuch less the equity - of such transactions.

Catholic social thought and praxis have long championed protection for workers given their vulnerability to abuse. The seminal social encyclical Rerum Novarum was a response to the abuses of the newly inaugurated industrial age of the nineteenth century (Leo XIII 1891). This was followed ninety years later by a commemorative encyclical, Laborem Exercens, that affirmed once again the importance of providing living wages and humane working conditions (John Paul II 1981). Its principle of the primacy of labor reminds business decision-makers that workers cannot be viewed merely as factors of production no different from capital or raw materials. Rather, they must be regarded for what they are-human beings-and must be treated accordingly, along with their dependents. Catholic social teaching has much to offer regarding widespread concern over poor or unsafe working conditions and pay in the mining sector. This is a central point of what could be called Catholic mining development ethics.

\section{One-sided revenue sharing between companies and host countries}

A second problem that arises in the mining sector is the lopsided nature of revenue sharing with the host country, stemming from the market's sole reliance on purchasing and bargaining power in consummating exchanges. Countries in the Global South are often compelled to enter into disadvantageous contracts with mining MNCs.

Empirical evidence from economic history tells us that most countries' economic center of gravity moves from agriculture to industry to services as they develop (Herrendorf, Rogerson, and Valentinyi 2013). Countries in the initial stages of their economic development rely heavily on their agricultural sector and mineral resources. Pre-Industrial Revolution United Kingdom output and pre-nineteenth century United States GDP were comprised predominantly of agriculture and mining. It is the same pattern that we see today. Contemporary Global South countries are heavily reliant on these sectors.

Such countries need to earn enormous sums of foreign exchange in order to pay for their imports of vital technology, raw materials, and capital goods. Mineral resources are a ready source of such foreign exchange, given the global demand for such commodities. Unfortunately, countries in the Global South often do not have the necessary capacity to extract, process, and sell these mineral resources themselves in global markets. They also do not have the funds to invest in what is often an extremely expensive and capital-intensive effort. They are thus heavily reliant on MNCs. This can lead to lopsided revenue-sharing contracts 


\section{Albino Barrera, OP}

between MNCs and host nations. Extra-market safeguards are needed to head off such uneven contracts. These include NGO advocacy, technical advice from multilateral agencies such as the World Bank and the United Nations, and international pressure against exploitative practices (see Mann 2015). Nevertheless, despite these extra-market interventions, we still have many disputes and allegations over exploitative revenue sharing arrangements between MNCs and host countries (see Burianski, Nyer, and Kuhnle 2019; Kimani 2009).

This is yet another illustration of a place where development ethics and Catholic social thought and praxis can offer needed extra-market norms in the mining sector. For example, MNCs should not view and treat host countries and local communities in a purely transactional manner, giving to the latter only that which is specified by their contracts or what is permissible under market operations. The principles of solidarity, universal destination of goods, subsidiarity, and integral human development call on these MNCs to treat their host countries and local communities as their equals. One-sided contracts are unacceptable because they are in effect taking advantage of the plight, ignorance, or weakness of one's trading partner. This is exploitation. The universal destination of goods is an affirmation that the earth is meant to benefit all, regardless of how titles of ownership are assigned. Integral human development should remind MNCs that authentic development is a joint effort that can only be completed together. The principle of subsidiarity should make them sensitive to their obligations to use their advantages in technical know-how, knowledge of markets, and vast experience in mining to good effect in helping poor nations and local communities develop and benefit from their natural resources. They are unable to do so on their own for want of the technical skills, capital, and market networks-the very strengths of the MNCs. Indeed, Catholic social thought can go a long way in making MNCs see that the mining industry is an ideal venue not only to maximize returns for their shareholders, but more importantly, to make a difference in the lives of people. Unlike international arbitrators and multilateral agencies, Catholic social thought cannot legally compel MNCs, but they can do something even better-appeal to their better selves via reason.

\section{Mining and the sharing of revenues within the host country}

Markets work toward allocative efficiency, not equity. Markets merely facilitate economic exchanges and are not concerned with their distributional consequences. Markets do not second-guess the equity of these economic transactions because they do not limit inequality. In fact, the logic of survival of the fittest can turn it into a form of buccaneer capitalism-a winner-take-all economy. Thus, it is entirely possible for the gains and benefits produced by markets to be concentrated in the hands of a few within the country (Piketty 2017). 
Nigeria is an example of the failure of oil wealth to lift the general population out of poverty (Slav 2018). In contrast, note the example of Norway and its disposition of its share of North Sea oil proceeds (Norges Bank n.d.). These differing examples underscore the importance of extramarket oversight and intervention (e.g., Norwegian public policy) in guiding market processes and in shaping market outcomes.

The principles of solidarity and relative equality from Catholic social thought and praxis are useful tools for development ethics in attending to these limitations in the extractive sector. The principle of solidarity calls for a genuine and active concern for the well-being of others because we see in them ourselves and a fellow child of God. The neighbor is viewed and treated as an equal. It is unacceptable to have pockets of great wealth and power amidst a vast sea of poverty because it reflects indifference to the plight of the poor and creates conditions that contribute to violent conflict. Moreover, relative equality is a necessary condition to achieving harmony in any community. Beyond a certain threshold, inequalities in wealth, power, and lifestyles not only breed dangerous social unrest, but they also mean that substantial segments of the population do not have the necessary resources to participate meaningfully in the common socioeconomic life. Thus, inequalities can only be permitted to go so far in any functional community.

\section{Inadvertent material cooperation in wrongdoing}

As mentioned earlier, markets are merely social institutions that allocate burdens and benefits across the community based on purchasing and bargaining power. On their own, they are not designed to make normative judgements on the resulting market outcomes. Thus, it is fairly common for market participants to unwittingly enable wrongdoing somewhere in the community. After all, market decisions have extensive ripple effects, both beneficial (positive externalities) and adverse (disexternalities). Market participants' resulting material cooperation in wrongdoing down the line can either be blameworthy or blameless, depending on whether or not they could have taken preemptive or remedial action to prevent or mitigate the subsequent wrongdoing.

For example, the enormous wealth that the mining sector produces creates numerous problems, such as engendering corruption and providing revenues for the waging of war or violence. Hence, we have the campaign against "blood diamonds" and the push to identify the source of coltan in the manufacture of cell phones (Campbell 2012; Nest 2011). The chapter by Rigobert Minani in this book explains how coltan funded war in the Democratic Republic of the Congo. Besides fueling such conflicts, mining can also unwittingly enable corrupt or failing governments, as was also the case in the Democratic Republic of the Congo, with corruption funneling mining revenues into the pockets of officials in the Kabila regime. Sierra 
Leone's vast diamond resources have been both a blessing and a bane, engendering frenzied theft and corruption, not to mention the thousands of lives lost from the wars that such diamonds funded and sustained.

The helplessness of markets in the face of these harmful ripple effects shows the need for development ethics in preventing or at least minimizing these unintended consequences from mining's huge revenue streams. There are many historical instances of extra-market interventions to prevent markets from enabling wrongdoing, such as the Kimberly Process to certify diamonds being conflict-free, or the United States' Dodd-Frank Act that required US companies to not source minerals connected to violent conflict.

To summarize the elements of this issue, markets allocate according to purchasing and bargaining power, with allocative efficiency as the primary goal that trumps all other possible goals of the economy. Concerns in mining development ethics over poor working conditions, economic compulsion, one-sided revenue sharing contracts, and great inequality are not unique to Catholic thought and praxis. There is widespread agreement on the need to address these market deficiencies, but Catholic moral theology and Catholic social teaching lend useful resources and concepts for analyzing these situations. This includes the idea of material cooperation with evil, which can result either from wrongdoing or from failure to prevent wrongdoing when the capacity to do so is present.

\section{Issue \#3: Mining and markets' lack of social consciousness}

Markets do not go beyond contractual obligations because they are not designed for other types of obligations, such as moral obligations. One ethical problem that arises is the lack of social consciousness.

Scholars and policymakers have flagged the problem of extractiveexport enclaves with little forward or backward linkage to the rest of the country (see Phelps, Atienza, and Arias 2015). Backward linkage pertains to the supply chain supporting the extractive operations, such as the stream of engineers, technicians, capital equipment, fuel, raw materials, and sundry tools vital for the industry's operations. Extractive-export enclaves often import these from overseas and can avoid sourcing their requirements domestically. As a result, the local economy and the local community do not share in the economic value created by mining.

Forward linkages pertain to the further processing of extracted resources into their various intermediate or final products. Examples of such forward linkage includes the processing of extracted ores within the host country to produce raw metals that are in turn processed even further into end products such as steel sheets, wires, etc. Forward linkages are highly sought because of the jobs and industries they create within the host country. Clearly, it is in the interest of the host country to have vibrant backward and forward linkages with their mining sector, especially if these host countries are just starting on their development path with little else but their 
mineral wealth. Not only do the local citizens earn a livelihood, but just as importantly, they gain skills.

Unfortunately, extractive-export enclaves arise with little backward or forward linkages with the rest of the host economy. Consequently, we see pockets of great wealth and advanced development in the immediate region where extractive operations are located while the rest of the country languishes in poverty. Left on their own, markets will not correct such imbalance. In fact, economic theory itself may further support and strengthen such enclaves if it can be empirically shown that the host country has a comparative advantage in the extraction and export of such mineral resources and not in the further processing of such minerals due to the lack, for example, of capital and cheap energy sources.

Left on their own, markets are concerned only with fulfilling contractual obligations. Mining firms satisfy their obligations once they fulfill their contractual obligations to the host country or local community. The economics of markets is such that economic agents are under no obligation to further anything else beyond their own interests. Markets are not geared for enforcing or living up to moral obligations. Corporate social responsibility is an extra-market intervention or mechanism that pushes market participants to go beyond their own interests and think of the welfare of the larger community of which they are a part. In recent years, as discussed in the chapter by Douglass Cassel, there has been a push to develop stronger and more legally binding standards for business and human rights that are not as easily manipulated by corporations who can sometimes simply throw money at a community building project and think they have satisfied their obligations. But "corporate social responsibility" can often be practiced without real social consciousness, rather than with the more robust understanding that development ethicists or business and human rights advocates might put forward.

Development ethics raises the issue of the moral obligations of mining firms to help their host communities and countries along the path of development by giving them opportunities to move up the value chain or increase their value-added contribution to the local processing of the extracted minerals. Related to this, of course, is the danger of the opposite extreme of paternalism, of being overly directive in telling host nations how they ought to traverse their path to development. Of course, it is possible for local populations to choose not to move up the value chain and to be content with enjoying their share of the revenues from extractive-export enclaves. Thus, we have literature on "the natural-resource curse," in which entire populations become complacent, develop few skills or a work ethic, and end up worse off than their resource-poor neighbors (see Humphreys, Sachs, and Stiglitz 2007; Frankel 2010).

From a purely economic-contractual point of view, there are no economic, much less moral, obligations beyond what is stipulated in contracts. Not so for development ethics, and not so especially for Catholic social 
thought and praxis, for the following reasons. First, integral human development is about (1) the development of the whole person-body, mind, and spirit-and (2) the development of every person. This second requirement of integral human development means that it is a journey that can only be completed together with our neighbor. We cannot claim to have reached our own integral human development if our neighbor, whom we could readily help, wallows in unattended need. Clemens Sedmak's chapter explains how these tenets of integral human development connect to peacebuilding. They amount to a model of development that prioritizes conditions in which conflicts can be handled in ways that preserve co-being rather than having some actors, like mining corporations with huge political, economic, and legal advantages, trying to gain maximum benefits.

Second, we have two parts of the principle of subsidiarity. The first part of this principle notes that higher bodies should not arrogate for themselves functions that lower bodies or individuals are able to perform on their own. Private initiative is to be fostered. The second part of this principle balances the first part by observing that it is the obligation of higher bodies or individuals to step in and provide assistance once lower bodies or individuals are in trouble and no longer able to function on behalf of the common good (Barrera 2001, 263-65). By the second part of the principle of subsidiarity, mining companies are bound by moral obligations to assist in the promotion of the welfare of their host communities, and to assist with problems that require higher levels of coordination and resources, such as security or integrating local operations with national initiatives like peace processes. Note that these responsibilities apply not only to governments but to any entity that has the capacity and resources to address the community's unmet needs.

The unsatisfactory nature of extractive-export enclaves is an issue where both economics and Catholic social tradition converge in their respective positions. It is also an illustration of where extra-market intervention is needed because allocative efficiency itself may dictate that the country remain a commodity exporter, while higher-value processing is reserved for other countries that have the comparative advantage.

Both the principles of subsidiarity and integral human development are also relevant for the earlier issue of one-sided or coercive contracts (issue no. 2 above). To take advantage of people in their need or in their ignorance is exploitation. Such predatory conduct, however, is not limited to coercive or one-sided contracts alone. We can be just as predatory with a failure by omission when we fail to prevent harm when we could easily do so. Mining firms that can do more to further the well-being of their host communities ought to do so. The preferential option for the poor makes this obligation even more compelling in the case of impoverished host communities. Economic exchange has to be of mutual benefit to all parties. What constitutes mutual benefit is where development ethics and Catholic social tradition can make a difference. For Catholic social tradition, it is 
nothing less than integral human development. Moreover, for development ethics and Catholic social tradition, outreach to the local community beyond what market contracts stipulate is not supererogatory but is a moral obligation. The poorer and less secure the host communities, the stronger and the more extensive are the moral obligations.

\section{Issue \#4: Mining and market limitations due to ownership externalities}

The problem of ownership externalities has long been known in the economic literature (see Bator 1958, 351-79). Markets often fail to assign an accurate exchange price for goods and services because they are unable to properly account for all inputs. Economic agents are unable to see or are not liable for the full accounting of costs and benefits. Hence, they do not sufficiently value the benefits they are enjoying from "the economic commons." Market participants do not see that they have a "social mortgage" in being able to so readily and easily participate in market exchange. This is so because there are many costs and inputs to maintaining markets that are not accurately priced, if they are even included at all. For example, take the price of rare earth metals that are essential for electronics. It does not include previous decades' investments in developing the basic science and technical know-how that enables users to harness the unique properties of these minerals. Or, consider the global banking infrastructure and international arrangements that facilitate international trade. These institutions and formal and informal rules took centuries to build, often at great expense. These underlying, unseen costs and inputs are often taken for granted and are not priced into market exchange. Such accounting problems are called ownership externalities.

Ownership externalities are another reason that mining firms cannot limit themselves only to their contractual obligations to their host communities. These mining firms are drawing benefits from their host communities-benefits that would most likely not have been accurately priced into the revenue-sharing contract. For example, many of these host nations have had a long history of strife and nation-building. Costs were incurred over time in building up the social, human, and physical infrastructure of the host communities. These costs are often not fully reflected in the price of participating in the marketplace. Market participants are thus able to draw benefits from the marketplace without having to share in the cost of many vital inputs that make it possible for such local markets to exist. Thus, it is very likely that mining firms avail themselves of many benefits from their host communities that have not been properly priced by the marketplace. This is especially likely in the Global South where markets and government fiscal structures are still rudimentary. 
This is yet another area where the contributions of Catholic social thought and praxis stand out. Ownership externalities prevent us from establishing accurately what is due to others in the marketplace. This is a significant deficiency, because justice is about giving others their due. Catholic social tradition offers a solution to this dilemma because it sees social life as operating not merely on the basis of justice. In fact, justice by itself is insufficient. Justice must find its perfection in charity (see Aquinas 1911-1925, II-II, q. 23, art. 6,8$)$. Thus, in situations where what is due to others cannot be ascertained, it is incumbent on market participants to act on the basis of charity itself. Charity, by its nature, is unmeasured and entails self-giving. In practical terms, this means that in the event of uncertainty or difficulty in establishing what is due to others, it is better to be self-sacrificial and to give more according to one's means. For example, it is difficult to establish accurately our personal contribution to global warming because of our consumption or travel habits. Moreover, we are not obligated by law to compensate for such damage. Nevertheless, some people take it upon themselves to pay for voluntary carbon offsets or to curtail their own consumption as a matter of civic duty, principle, or conscience. In the sensibility of Catholic social tradition, they are motivated by charity. In the case of mining companies, they ought to do more for their host communities beyond what their contracts stipulate, not to promote their public image at home and abroad, but out of a genuine concern for the well-being of their host communities. Charity, in this sense, is to give without thought of return, thinking only of the good of the recipient.

In sum, the phenomenon of ownership externalities and subsequent mispricing in the marketplace are further arguments for why mining firms, or any other firms for that matter, have obligations over and above those stipulated by their contracts. Accounting difficulties in keeping track of inputs and the true social and private cost of goods and services they draw from the community impose these non-contractual obligations.

\section{Issue \#5: Mining and the market's inability to establish intrinsic or non-economic value}

The preceding issue on ownership externalities arises because of the technical limitations of accounting. Market prices are inaccurate because they do not include many unmeasured or incommensurable costs and benefits. But even if we assume, for the sake of argument, that we are able to arrive at accurate market prices, there is an even deeper problem: our inability to arrive at the true value of certain goods or services.

There is a difference between price and value. Price pertains to the quantity of currency to which buyers and sellers agree in order to consummate trade. Price is essential in order to effect economic exchange. Price is determined only by consumer sovereignty, that is, what people are willing to pay for such goods or services. In contrast, value pertains to the intrinsic worth of goods and services. 
This difference between price and value can be easily understood by recalling the water-diamond paradox of introductory economics classes. Water is clearly of much greater value compared to diamonds because it is essential for life. If so, why is the market price of diamonds manyfold that of water? The response is, of course, that market price is determined by scarcity. Given its greater abundance relative to diamonds, the market price of water is based on what consumers are willing to pay for the last use for which water can be employed, such as watering the lawn, flushing the toilet, or washing the car. Another example is the compensation of teachers and nurses. These professionals provide services that are vital for life and the well-being of the community. But their salaries, or market price, are far lower than their true value, that is, their intrinsic contribution to the quality of life.

A good scriptural illustration of the difference between exchange price, on the one hand, and intrinsic value, on the other hand, is the Jubilee Law (Lev. 25). The market price of land, when it changes hands, is the sum of the market price of the harvests that can be reaped from that land before it is returned in the next Jubilee year. In contrast, the intrinsic value of land is incalculable, or one could say, non-existent, because land belongs to God (Lev. 25:23), and humans are merely tenants. Thus, land cannot be sold in perpetuity, and only according to the market price of its harvests.

The market's limitation in determining the intrinsic value of goods and services is particularly worrisome in the case of mining, which involves the depletion of non-renewable resources. Economists have long been dissatisfied with the way natural resources are priced in the marketplace (see Nordhaus and Tobin 1973, 509-64). Take the case of the calculation of GDP, the sum total of all the goods and services produced within the borders of the nation. The natural resources that are extracted in a particular time period are incorporated into the calculation of GDP at the market price at which they were sold. Such pricing, however, is inaccurate, especially in determining the wealth of the nation, because the extraction, export, and use of such minerals means that there is less left for future generations of citizens. There is no intrinsic value ascribed to natural resources in the ground. They are priced only according to what they will command in the marketplace.

Similarly, the cost of the ecological damage that mining industries inflict is not properly priced or valued in the marketplace, as in the case of global warming caused by the burning of fossil fuels or the flaring of waste gas. Or, take the case of the enormous amounts of fresh water that are used in mining. The market price of metals and minerals does not incorporate the value of depleted or polluted water, but only what consumers are willing for pay for the mined products. The fresh water supplies used or damaged are not valued for their intrinsic worth, especially for future generations.

Development ethics has much work to do vis-à-vis this market deficiency. There is a need to change contemporary behavior and attitudes 


\section{2}

regarding the goods of the earth. Market participants should think in terms not only of the exchange price of these goods, but also of their intrinsic value. The calculation of a nation's GDP or of global wealth or income has to factor in the depletion of non-renewable resources. Incorporating intrinsic value into exchange value is relevant for two important issues: (1) revenue sharing with the host country/community and (2) intertemporal equity.

Host communities are clearly at a disadvantage if they are paid for their natural resources based only on exchange price, without taking into account the intrinsic value of these resources. Thus, host nations/communities are underpaid. Such misvaluation means that economic growth from mining is overstated, because the damage to the environment and the depletion of nonrenewable resources are insufficiently considered. This also means that it becomes even more difficult to attain or approximate contemporary allocative efficiency given the mispricing of factor inputs. Mispricing, in this case, is due to the mis-valuation of underlying goods and services themselves, instead of accounting limitations that give rise to the ownership externalities in the preceding issue.

Mis-valuation is central to the issue of intertemporal equity. Nonrenewable resources are undervalued, and as a result, they are misused or over-used. Consequently, there is a much faster rate of exhaustion of these supplies of non-renewable resources than is warranted. There will be that much less for the next generations as part of their patrimony from contemporary generations.

Mis-valuation is relevant not only for intergenerational equity but also for intertemporal allocative efficiency. One justification for the use of nonrenewable resources by earlier generations was that they are able to expand technological know-how and improve the stock of capital for the benefit of succeeding generations. In other words, in exchange for a smaller supply of non-renewable resources, future generations will be able to enjoy a much more advanced technological base and be equipped with more capital. There is a trade-off between conserving non-renewable resources for the sake of future generations and the amount of know-how and capital that the current generation is able to bequeath them. There is need to find a balance between pushing the envelope of contemporary technologies, on the one hand, and keeping natural resources undeveloped and untapped, on the other hand, in order to conserve them.

Solving for intertemporal allocative efficiency is a much more complex process than that of finding out what contemporary allocative efficiency requires. We compound this difficulty by using the wrong valuation of these non-renewable resources because we are using only their exchange price and have not incorporated their intrinsic value. The major difficulty, of course, is in establishing the intrinsic value of various resources. This is an area of possible collaboration between the fields of development ethics, public policy, and economics. 
Imputing intrinsic value is a technical field. Nevertheless, Catholic social thought still has an important contribution to make: a rationale for imputing intrinsic value to the goods of the earth over and above their exchange value. The goods of the earth are a gift from God meant to benefit all, both in the present and in the future. This principle of the universal destination of goods is vividly affirmed in the creation accounts in Genesis. Humanity is entrusted with the mandate to exercise stewardship over God's creation, even as we draw from the earth whatever it is we need for daily living.

A final word of caution: imputing value to mineral resources based on their intrinsic worth will increase current prices of these commodities. Such price increases will in effect be a de facto redistribution of income and wealth. For example, people with a large portion of their budgets devoted to the purchase and use of mineral resources will find their real incomes shrink. In other words, mining development ethics and Catholic social thought would require sacrifice on the part of current market participants. Of course, this is not the first time that people have been invited to willingly sacrifice their current consumption, as in the case of carbon taxes and voluntary carbon offsets. The principle of solidarity is important in this regard-solidarity with brothers and sisters yet unborn.

\section{Issue \#6: Mining and the question of ownership and usufruct of the goods of the earth}

I have reserved for last the most intractable problem, but the most fundamental one that must be addressed. Markets merely accept, and do not second guess, the ownership-usufruct framework set by the extra-market legal institutions prevailing in the communities in which they operate. In contrast, nations, political economies, development ethics, and indeed the community of nations must address or constantly revisit fundamental questions, such as: who owns the goods of the earth, who should have usufruct rights over them, and how should the costs and benefits from these resources be distributed across the community? These bedrock issues determine how extractive activities are conducted and how their costs and benefits are distributed.

In the case of mining, there is a longstanding de facto global rule that nations exercise ownership and usufruct rights over natural resources within their borders. The 1982 UN Convention on the Law of the Sea sets a two-hundred-mile exclusion zone offshore for purposes of delineating the boundaries of nations' economic claims (art. 57; see also Hollick 1977). Governments have pursued different paths to making use of these natural resources. Some have nationalized extractive industries in key natural resources, such as oil. Others rely on a more market-based approach of letting private firms extract and sell these natural resources in exchange for taxes, lease payments, and revenue sharing, among many other methods. 


\section{Albino Barrera, OP}

These different approaches have significant ramifications for who bears the cost and who reaps the benefits. For example, nationalized extractive industries better benefit the general population (at least in theory), while a more market-oriented approach allows entrepreneurs who undertake the risks of development and investment to reap most of the benefits, as in the case of the United States and other Global North nations.

Of concern for us is the question of which method is appropriate. The criteria for making this assessment vary depending on the philosophical commitments of evaluators. Neoclassical economics would most likely privilege allocative efficiency as the measure to use, while development ethics and Catholic social tradition would most likely use a combination of all six socioeconomic goals in varying degrees, again depending on the priorities of the evaluators. Despite this difficulty and the lack of consensus on an ideal or common standard for evaluation, the question of which method is appropriate for mining has to be addressed head on because it directly impinges on the distribution of the burdens and benefits of the metals and minerals, for contemporary generations but also, of equal import, for future ones.

The question of which approach is appropriate points us to even more fundamental questions that we must constantly revisit: (1) Where do we draw the line of ownership and usufructuary rights: at the local, provincial, national, regional, or global level, or a combination of these, and (2) on what bases do we do so? Who exercises rightful ownership and usufructuary claims over these resources? For example, who ought to have ownership-usufructuary rights to the shale basin in the North American continent? The local communities, the state, or the federal government? The main contribution of Catholic social thought in this regard is its principle of the universal destination of goods. Should Catholic social tradition advocate for the global patrimony of all key natural resources in light of its universal access principle (Pontifical Council for Justice and Peace 2004, \$171-184) and its fundamental premise that the goods of the earth are a gift for all from God, meant to benefit all? Where does one draw the line?

These fundamental questions have ramifications for all the other issues and questions downstream. For example, do national governments have the right to assign property or usufructuary rights over natural resources to private groups? Do nations have the right to nationalize and benefit exclusively from their resource wealth, or should there be a global fund that distributes these resources worldwide in view of the central importance of metals and minerals in the modern industrial economy and given the universal access principle? Can nations use extractives as instruments of foreign policy, as in the case of the two oil embargoes of the 1970s? Given their vital role in the digital age, should rare earth minerals be considered a global patrimony rather than be controlled by the nations in which they are found? ${ }^{4}$ 
Even if we were to make the heroic assumption of a global acceptance of the universal access principle, we nevertheless have to balance this with the pragmatic reality of having to avoid the tragedy of the commons and the very real problem of free-ridership. There will still be a need to provide incentives for risk-taking. Work effort and initiative will have to be properly compensated. Nevertheless, satisfying these requirements simultaneously requires much deliberation. We have to find a balance between the Lockean claim to property ownership ${ }^{5}$ and the Lockean proviso. ${ }^{6}$

In sum, the questions of who owns and who has usufructuary rights over the goods of the earth and on what bases must be addressed because they determine the distribution of burdens and benefits from the mining sector. They are relevant in arriving at the appropriate arrangements in extracting natural resources, such as whether or not such activities should be nationalized or privatized. Markets simply operate within the formal and informal norms set by the community. Development ethics has a hand in shaping these formal and informal rules. In the absence of extra-market norms, market praxis becomes the norm by default based on purchasing power and existing ownership claims, no matter how unsatisfactory or damaging they might be. The absence of such norms can invite conflict over ownership and prevent mining operations from being harmonized with other objectives, like brokering or implementing peace agreements or ensuring environmental protection.

\section{Conclusion}

Development ethics is not an optional add-on to development economics or market operations. Rather, it is necessary given the significant limitations of market processes and outcomes. Extra-market oversight and intervention are needed because markets, on their own, will not attend to the community's well-being, only to the allocative efficiency of its scarce resources. In fact, the whole field of development ethics is about the need for extramarket intervention because left on their own, unfettered market operations are unable to reach larger societal goals, like implementing peace or advancing integral human development. Extra-market institutions are a necessary condition for markets to operate smoothly and sustainably. They are needed if markets are to exist at all, and we see this phenomenon in the mining sector.

Some issues in mining development ethics are fairly straightforward and uncontroversial for most reasonable people, such as the need to rectify pollution and damage to the environment, the need to improve safety and working conditions, the inappropriate use of enormous revenues from natural resources for war and civil strife, the skewed revenue-sharing from onesided contracts, the inequality in the distribution of revenues within the host nations and local communities, and the danger of fostering corruption in the host communities. Other issues are gray areas, such as intergenerational 
equity, the problem of distant harms and where the limits of responsibility are, and the obligation of mining sectors not to be isolated export enclaves but to help their host nations to move up the value chain of economic activity. There are also the questions of the proper valuation of the goods of the earth and of who should exercise ownership-usufructuary rights over the goods of the earth.

What is distinctive with Catholic social thought and praxis vis-à-vis these issues and extractive development ethics? First, it has a holistic understanding and practice of development. Another name for peace is development (Paul VI 1967, \$76-77). Development is a necessary condition for peace. However, it is not a sufficient condition. There is need to strike a balance between two extremes. On the one hand, there is the danger of an otherworldly dismissive attitude that views socioeconomic life as mundane, secondary, or unimportant. There is a necessary economic dimension to human flourishing. Getting our economics right is important as part of human nature since we are corporeal and social. For example, even as we acknowledge the need to impute an intrinsic value to mineral resources beyond their exchange value, we must be realistic as well in recognizing that arriving at such a value is extremely difficult. Even more difficult is implementing it in practice, especially in light of the much higher prices that will lead contemporary generations to curtail their consumption.

On the other hand, there is also need to avoid the other extreme of economism, that is, of privileging economic factors above all else. From this viewpoint, development is primarily an economic phenomenon and is measured by economic growth. In contrast, Catholic social tradition is adamant that economics is not an end in itself but is merely instrumental. It is at the service of integral human development. As we have seen above, there is a two-fold nature to integral human development: (1) the development of the whole person (which explains why development is not merely nor primarily economic) and (2) the development of every person (which explains the importance of distribution and mutual benefits in economic exchange). Catholic social tradition proposes a much broader definition of development and imbues it with much larger goals. Our neighbor's development is our development too, and vice versa. We are necessary conditions to each other's development. This has enormous ramifications for mining firms' obligations to all their stakeholders. It means that their relationship with their stakeholders is not merely contractual, as the markets would have it, but is familial in nature, especially for their workers and their host communities. They are invited to act accordingly.

Another risk of economism is assuming that economic growth is a direct line to peace. Violent conflict often involves many factors that are not merely economic, such as historically rooted animosities, political power, or competing claims about the value of land being mostly about its resources versus being about ancestral claims for indigenous heritage. Assuming economic growth can in and of itself solve challenges of peace ignores other 
needed elements and processes. And at times, development ethics might call for allocative efficiency and market growth in the mining sector to stand aside to allow other priorities to supersede them.

A second distinctive Catholic social tradition contribution is that, as new creatures in Christ, humans ought to act according to who they have become. Thus, for Christians working in the mining sector, good works should flow from their faith. Mining development ethics should become integral in their conduct-and not merely for post-hoc damage control, but intrinsic right from the very start. Mining ethics is not deontological, with a list of dos and don'ts, but is teleological, because it pushes people to better self-understanding and considers the vocation of all Christians to strive for peace and the common good.

Third, the Catholic social tradition holds that creation is a gift from God meant to benefit all. Such a conviction creates two claims for mining development ethics. First, all are accountable to the Creator. The proper attitude to take, vis-à-vis the goods of the earth for all mining firms, their shareholders, and national governments, is not a proprietary posture, but one of stewardship. There are limits to what we can do with the goods of the earth. Second, there is the moral obligation to ensure that all are able to benefit from the goods of the earth regardless of how titles of ownership are assigned.

\section{Notes}

1 For example, most communities use social safety nets to define a "moral floor" beneath which people will not be allowed to sink. Western capitalism give preeminence to individual liberties and the free pursuit of private initiatives, while state capitalism stress the central role of government in political economy.

2 Note the long simmering anti-globalization movement dating back to the 1990 s (see Juris 2008) and the current contentious dissatisfaction with markets in light of worsening inequality at a time of vibrant economic growth at both the national and global levels (see Occupy Wall Street n.d.).

3 See the efforts of the members of the International Council on Mining and Metals (n.d.) in promoting sustainable industry practices.

4 These are examples where it is probably better to leave markets alone, where extra-market institutions or interventions become a liability by allowing economic activity to be a weapon or tool in the pursuit of national interests.

5 This entails property ownership over the goods of the earth that one has made productive with one's initiatives and effort (Locke 1988 [1689], sec. 2, para. 27).

6 In claiming rightful property ownership, we are bound by the obligation to leave "enough and as good" in the commons so that others, too, might have a chance to secure such property rights for themselves (Locke 1988 [1689], sec. 2, para. 26, 32).

\section{References}

Aquinas, Thomas. 1911-1925. Summa Theologica. Translated by Fathers of the English Dominican Province. New York: Benziger Brothers. 
Barrera, Albino. 2001. Modern Catholic Social Documents and Political Economy. Washington, DC: Georgetown University Press, 2001.

Bator, Francis M. 1958. "The Anatomy of Market Failure.” The Quarterly Journal of Economics 72: 351-379. 10.2307/1882231.

Burianski, Markus, Damien Nyer, and Federico Parise Kuhnle. 2019. "Resolving Disputes in Africa's Mining Sector." Africa Focus. https://www.whitecase.com/ publications/insight/resolving-disputes-africas-mining-sector.

Campbell, Greg. 2012. Blood Diamonds: Tracing the Deadly Path of the World's Most Precious Stones. New York: Basic Books.

Francis. 2015. Laudato Si'. http://www.vatican.va/content/francesco/en/encyclicals/ documents/papa-francesco_20150524_enciclica-laudato-si.html.

Frankel, Jeffrey. 2010. “The Natural Resource Curse: A Survey.” NBER Working Paper No. 15836. 10.3386/w15836.

Gasper, Des. 2012. "Development Ethics: Why? What? How? A Formulation of the Field." Journal of Global Ethics 8, no. 1 (2012): 117-135. 10.1080/17449626.2 012.672450 .

Goulet, Denis. 2006. Development Ethics at Work: Explorations 1960-2002. New York: Routledge. 10.4324/9780203086643.

Humphreys, Macartan, Jeffrey Sachs, and Joseph Stiglitz, eds. 2007. Escaping the Resource Curse. New York: Columbia University Press.

Herrendorf, Berthold, Richard Rogerson, and Ákos Valentinyi. 2013. "Growth and Structural Transformation.” NBER Working Paper No. 18996. 10.3386/w18996.

Hollick, Ann. 1977. "The Origins of 200-Mile Offshore Zones.” American Journal of International Law 71, no. 3: 494-500. 10.1017/S0002930000106499.

International Council on Mining and Metals. n.d. "Environment." Accessed December17, 2020. https://www.icmm.com/en-gb/environment.

John Paul II. 1981. Laborem Exercens. https://www.vatican.va/content/john-paulii/en/encyclicals/documents/hf_jp-ii_enc_14091981_laborem-exercens.html.

Juris, Jeffrey. 2008. Networking Futures: The Movements Against Corporate Globalization. Durham, NC: Duke University Press. 10.2307/j.ctv11sn2g6.

Kimani, Mary. 2009. "Mining to Profit Africa's People." Africa Renewal. https:/www.un.org/africarenewal/magazine/april-2009/mining-profit-africa\%E2 $\% 80 \% 99$ s-people.

Leo XIII. 1891. Rerum Novarum. https://www.vatican.va/content/leo-xiii/en/ encyclicals/documents/hf_l-xiii_enc_15051891_rerum-novarum.html.

Locke, John. 1988 (1689). Two Treatises of Government. Edited byPeter Laslett. Cambridge, UK: Cambridge University Press.

Mann, Howard. 2015. IISD Handbook on Mining Contract Negotiations for Developing Countries. Volume 1: Preparing for Success. Winnipeg, Canada: International Institute for Sustainable Development. https:/www.iisd.org/ publications/iisd-handbook-mining-contract-negotiations-developing-countriesvolume-1-preparing.

Martinez-Alier, Joan. 2001. "Mining Conflicts, Environmental Justice, and Valuation." Journal of Hazardous Materials 86: 153-170. 10.1016/s0304-3894 (01)00252-7.

McBeth, John. 2018. "Indonesia Pollution Charge Piles Pressure on Freeport." Asia Times, May 9, 2018. http://www.atimes.com/article/indonesia-pollution-chargepiles-pressure-on-freeport. 
Mills, Catherine. 2010. Regulating Health and Safety in the British Mining Industries, 1800-1914. London: Routledge. 10.4324/9781315244884.

Nest, Michael. 2011. Coltan. Cambridge, UK: Polity.

Nordhaus, William D. and James Tobin. 1973. "Is Growth Obsolete?" In The Measurement of Economic and Social Performance, edited byMartin Moss, 509-564. New York: National Bureau of Economic Research. https:// www.nber.org/books-and-chapters/measurement-economic-and-social-performance.

Norges Bank. n.d. “About the Fund.” Accessed January18, 2019. https://www.nbim.no/ en/the-fund/about-the-fund.

Occupy Wall Street. n.d. “About.” Accessed January18, 2019. http://occupywallst.org/ about/.

Okonta, Ike, and Oronto Douglas. 2001. Where Vultures Feast: Shell, Human Rights, and Oil in the Niger Delta. San Francisco: Sierra Club Books.

Paul VI. 1967. Populorum Progressio. http://www.vatican.va/content/paul-vi/en/ encyclicals/documents/hf_p-vi_enc_26031967_populorum.html.

Phelps, Nicholas, Miguel Atienza, and Martin Arias. 2015. "Encore for the Enclave: The Changing Nature of the Industry Enclave with Illustrations from the Mining Industry in Chile." Economic Geography 91, no. 2: 119-146. 10.1111/ecge.12086.

Pigou, Arthur Cecil. 2013 (1920). The Economics of Welfare. London: Palgrave Macmillan.

Piketty, Thomas. 2017. Capital in the Twenty-First Century. Translated byArthur Goldhammer. Cambridge, MA: Belknap Press of Harvard University Press. $10.4159 / 9780674982918$.

Pontifical Council for Justice and Peace. 2004. Compendium of the Social Doctrine of the Church. http://www.vatican.va/roman_curia/pontifical_councils/justpeace/ documents/rc_pc_justpeace_doc_20060526_compendio-dott-soc_en.html.

Slav, Irina. 2018. "Nigeria Rated Poorest Country Despite Oil Earnings.” OilPrice.com, July 4, 2018. https://oilprice.com/Latest-Energy-News/World-News/Nigeria-RatedPoorest-Country-Despite-Oil-Earnings.html.

United Nations Convention on the Law of the Sea. 1982. Montego Bay, December 10, 1982. United Nations Treaty Series, vol. 1833, no. 31363. https://treaties.un.org/ Pages/ViewDetailsIII.aspx?src=TREATY\&mtdsg_no=XXI-6\&chapter=21\&Temp= mtdsg3\&clang=_en. 